\title{
The effect of bubble size distribution on the release of microalgae proteins by ozone- flotation
}

\author{
Gislayne Alves Oliveira ${ }^{1}$ - Ignacio Monje-Ramirez ${ }^{2} \cdot$ Elvis Carissimi $^{1} \cdot$ Rafael Teixeira Rodrigues $^{3}$. \\ Sharon B. Velasquez-Orta ${ }^{4}$ Alma Concepción Chávez Mejía ${ }^{2}$ "María Teresa Orta Ledesma ${ }^{2}$ \\ ${ }^{1}$ Departamento de Pós Graduação em Engenharia Civil, Centro de Tecnologias, Universidade Federal de \\ Santa Maria, Camobi, CEP 97105-900, Santa Maria, RS, Brasil \\ ${ }^{2}$ Instituto de Ingeniería, Coordinación de Ingeniería Ambiental, Universidad Nacional Autónoma de México, \\ Ciudad Universitaria, CP 04510, CDMX, México \\ ${ }^{3}$ Departamento de Engenharia de Minas, Universidade Federal do Rio Grande do Sul, Av. Bento Gonçalves, \\ CEP 91501-970, Porto Alegre, RS, Brazil \\ ${ }^{4}$ School of Chemical Engineering and Advanced Materials, Newcastle University, Newcastle Upon Tyne \\ NE1 7RU, England, UK
}

\begin{abstract}
Interest in sustainable energy production is one of the most important resources in the development of technologies, and one of the promising sources is the use of microalgae as a raw material. These are obtained in nature, do not need good conditions to develop, occupy a small area for growth and replace the use of food products for the production of biofuel. However, one of the biggest hurdle is the biomass harvest and one of the innovative techniques being proposed is ozone-flotation. Flotation processes are influenced by the physical characteristics of bubbles and particles, and therefore it is necessary to investigate the size distribution of generated bubbles, their action in microalgal cells and the oxidation and release of proteins that act as biosurfactants. In this work the effect-of ozone bubble size in a three-phase system (ozone - wastewater microalgae) and size of microalgal particles separated by ozone-flotation were evaluated. Three ozone flows were used $(0.2,0.6$ and $1 \mathrm{~L} / \mathrm{min})$. Best results were obtained with a flow of $0.6 \mathrm{~L} / \mathrm{min}$ achieving $88.5 \%$ efficiency, increased biomass oxidation, destabilization of microalgal cells (zeta potential $3.17 \mathrm{mV}$ ), highest protein release $(46.7 \mathrm{mg} / \mathrm{L})$ and, a demonstrated efficiency of proteins in reducing bubble coalescence. Regarding the latter, no differences in size or distribution of the ozone bubbles were obtained between the 3 evaluated heights of the column (bottom, middle and top). At this flow the mean bubble diameters were maintained at 1910, 2028 and $2071 \mu \mathrm{m}$ for bottom, middle and top, respectively, with approximately $50 \%$ of the bubbles concentrated up to $2000 \mu \mathrm{m}$. In addition, due to the higher action of ozone with microalgal cells, smaller particle sizes in the column were found due to the oxidizing action of ozone.
\end{abstract}

Keywords: Scenedesmus sp.; Wastewater; Biosurfactant; Ozone bubble size; Digital image analysis.

* Corresponding author. Tel.: +52(55)56233600 Ext.: 3672; fax: +52(55)56162164.
E-mail address: tol@pumas.iingen.unam.mx 


\section{Introduction}

The use of microalgae as a source of biofuel has stood out as a renewable raw material in part because many of the resources required for mass cultivation can be supplied by sewage [1] which promotes the removal of nutrients and metal ions [2,3]. When compared to fossil fuels, microalgae biofuels are renewable, biodegradable, and an important non food-based alternative [4] . Microalgae are fast growing in adequate environmental conditions and produce significant amounts of lipid and carbohydrates, in a small footprint.

However, one of the major challenges for using microalgae in biofuel production is an efficient harvesting method. Normally, harvesting processes are based on different physicochemical and biological properties of microalgae. Flotation has emerged as a promising unit operation for microalgae harvesting due to the tendency of microalgae to float instead of settle, and less energy is used compared to centrifugation. In order to achieve adequate contact angle between bubbles and microalgae, the cells of the microalgae must be hydrophobic; this can be achieved through the addition of surfactants or coagulants [5] which alter the dynamic properties of the interface, and therefore affect the surface charges and the stability of the foam during flotation [6]. Added chemicals aim to enhance particle separation, increase contact between air and solid particles and improve the likelihood of adhesion [7]. However, the presence of metal ions in biomass resulting from coagulants can become problematic for downstream processes [8] since it is toxic to the cells [9]. In this case the application of ozone flotation is an advantageous method that does not require flocculants or to lower the $\mathrm{pH}[10]$ and, instead, stimulates the flotation capacity of microalgae.

Bubble-particle interactions have been widely shown to be the most important sub-process in flotation [11]; bubbles are the key of flotation, where bubbles attach to hydrophobic particles and carry them to the froth layer [12]. Within the liquid pool, bubble motion facilitates mixing and therefore increases the likelihood of algae/bubble interaction [13]. The bubbles provide the interface for microalgal cell binding and carry the microalgae bound to the foam-liquid interface [14].

The main individual elementary steps of flotation are the collision of a solid particle with a bubble, attachment and adhesion of a particle to a bubble and detachment of a particle from a bubble [12,15-21]. The collection mechanism is one in which the bubbles attach to hydrophobic particles or microalgae the formation of a finite contact angle at the gas-liquid-solid contact line [22].

An effective way to improve interaction, binding and stability efficiencies in the bubble/microalgae relationship is to reduce the size of the bubbles, thus increasing the surface area per unit volume and increasing the probability of interaction between bubbles and algae [23]. Apart from size, small bubbles also affect the mass transfer of ozone, and help decrease the use of excess costly ozone. In ozone flotation, ozone bubbles cause oxidation when in contact with microalgae cells, releasing proteins that exhibit surfactant properties, and thus reduce the surface tension of water [22].

The addition of surfactants reduces bubble coalescence and push bubbles in the slurry zone towards the foam phase, due to an increase in air bubble residence time [24]. Ozone also reduces the surface charge of cells (measured in terms of zeta potential) and increases the extraction of lipids and carbohydrates due to its 
oxidizing action. Proteins released from highly bound allogenic organic matter are essential for both modifying the hydrophobicity of bubble surfaces for easy cell attachment and for forming an upper foam layer to collect floating cells [25].

There are currently few works that have evaluated the bubble-particle relationship in flotation, and the majority of such literature is for two-phase systems, because three-phase systems (solid-liquid-gas) are particularly complex [26]. Additionally, the bubble-microalgae relationship is strongly related to the transfer of ozone mass to the cells of microalgae which cause a reduction in the surface charge of the cells, thereby causing these microalgae to agglomerate and float. Also, ozone oxidizes the cells favoring liberation of biomolecules, including proteins that reduce the surface tension of water.

The three-phase system works with minerals, with air-water-quartz and talc [27], air-water tap waterglass particles [12], air-Milli Q water-alumina and silica [28], water-air-phosphate ore [24], air-water-silica [29], air-water-quartz [30], and air-water-barite [31]. Coward et al. [14] evaluated the size of air bubbles with different spargers with Chlorella, but determined the size of the bubbles before harvest with the addition of the cationic surfactant cetyltrimethylammonium bromide (CTAB). Beneventi et al. [32] used the ozone flotation column for deinking papers and determined the size of the bubbles and the transfer coefficient of ozone, but to determine the size of the bubbles the authors used air bubbles.

The aim of this work was to investigate, for the first time, the effect of ozone bubble size distribution and microalgal size in a three-phase system (ozone-wastewater-microalgae). Three ozone flow setups were used to evaluate the effect of protein release as a biosurfactant, helping in the coalescence of ozone bubbles by ozone flotation.

\section{Materials and Methods}

\section{Cultivation of Scenedesmus sp. in wastewater}

The biomass used was obtained from the cultivation of microalgae containing a majority of Scenedesmus sp. grown in raw wastewater from a Wastewater Treatment Plant from the Facultad de Ciencias Políticas y Sociales, Universidad Nacional Autónoma de México. The microalgae was produced in a High Rate Algal Pond (HRAP) at lab scale with a capacity of $30 \mathrm{~L}$, cultivated in a ratio of $14 \mathrm{~L}$ of wastewater to $14 \mathrm{~L}$ of microalgae culture. Biomass concentration as total suspended solids (TSS) was determined, indirectly, by gravimetry using standard methods (APHA 2005). The amount of biomass harvested was calculated by dividing the biomass harvested by the initial biomass concentration and the oxidized biomass was calculated from the initial biomass by subtracting the harvested biomass and the biomass that remained in the flotation column. The particles of microalgae were visualized in Axio Lab.A1 microscope combined with the Axiocam ERc 5s microscope camera to capture the images of the microalgae cells that were modified and measured the particle size (130 particles) of 20 captured images in the Zen imaging software. The particle size distribution for the 
initial biomass were determined using a LS 13320 Laser Diffraction Particle Size Analyzer coupled to Universal Liquid Module (ULM), which is based on the principle of diode laser light scattering ensemble.

\section{Ozone Flotation}

Ozone-flotation experiments were carried out in batch and bench scale using $1 \mathrm{~L}$ of a freshly homogenized culture of Scenedesmus sp. in a glass column reactor (height: $66 \mathrm{~cm}$, inner diameter: $4.9 \mathrm{~cm}$ ) with closed in line system avoiding the ozone flight. The ozone produced by to a Labo 76 ozone generator (Emery Trailigaz, USA) with a production capacity of $19 \mathrm{~g} \mathrm{O}_{3} / \mathrm{h}$, was injected in the bottom of the reactor using a glass diffuser (10-15 $\mu \mathrm{m}$ pore size) located in the central axis of the cell, which dispersed the ozone in the liquid medium with different ozone flow rates $(0.2,0.6$ and $1 \mathrm{~L} / \mathrm{min})$ for 20 minutes and ozone gas concentration in the gas phase $(18.2,6.67$ and $4.22 \mathrm{mg} \mathrm{O} / \mathrm{L})$, in order to apply a dose of $0.16 \mathrm{mg} \mathrm{O}_{3} / \mathrm{mg}$ of dry biomass and a biomass concentration of $500 \mathrm{mg} / \mathrm{L}$. The ozone concentration in the gas phase used for each test was determined using the Iodometric Method [33]. The percentage of transferred ozone was calculated as follows:

$$
\% \text { Transferred ozone }=\left(\frac{\text { Ozone In-Ozone Out }}{\text { Ozone In }}\right) * 100 \%
$$

\section{Bubble size determination}

Bubbles generated during ozone-flotation were measured in a three-phase system (wastewater-ozonemicroalgae) applying a visual technique with image analysis. The images were captured by a NIKON D3400 digital still camera with an AF-S DX MICRO NIKKOR 400 MM lens positioned at a suitable distance (29.7 $\mathrm{cm}$ ) from the flotation column for focus adjustment. Shutter speed was 1/1000 and ISO sensitivity of 400, this allowed to capture bubble images without blur. The flotation column was backlit using illumination assisted with a cold light, with three vertically mounted Osram T8 $10 \mathrm{~W}$ LED lamps. One lamp was placed on the opposite side of the camera and the other two on the sides of the flotation column. Example of the obtained photograph are shown in Fig. 1.

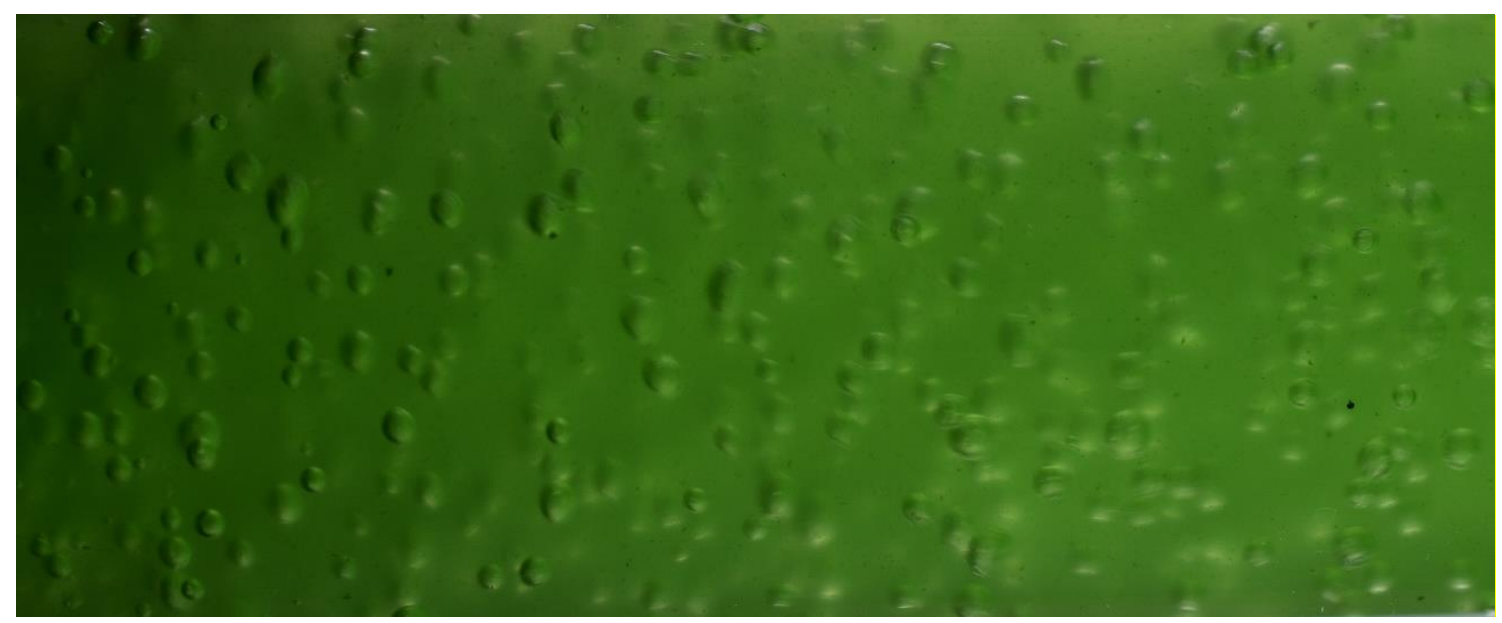


Fig. 1 Example of the obtained photograph by ozone-flotation to determine bubble size.

A computer with special software for image data processing and analysis (Image Tools) was used. Image size obtained was 6000 x 4000 pixels (24 Megapixels) and 24 bits color. The Image processing basically included the following steps: calibrate spatial measurements (for the transformation of number of pixels to $\mu \mathrm{m}$ ), and then draw lines over the bubbles to determine the diameter of each bubble.

Due to the great turbidity of the water caused by the microalgae, the images were captured after 5 minutes of ozone flotation so that ozone could react with microalgae by releasing proteins to harvest biomass. A ruler was placed inside the flotation column with the culture to calibrate the images by conversion to pixel number; this was done for each height of column and ozone flow.

To evaluate the coalescence of bubbles, the images were captured $3 \mathrm{~cm}$ from the bottom of the flotation column; from the middle of the column the images were captured $25 \mathrm{~cm}$ from the bottom and from the top, 55 $\mathrm{cm}$ from the bottom. About 300 bubbles [14,32] (10 images) were measured manually (software Image Tools) for the determination of the size distribution in each experimental run. The mean bubble diameter adopted was the Sauter diameter, calculated by equation:

$$
\mathrm{d}_{32}=\frac{\sum \mathrm{n}_{\mathrm{i}} \mathrm{d}_{\mathrm{bi}}^{3}}{\sum \mathrm{n}_{\mathrm{i}} \mathrm{d}_{\mathrm{bi}}^{2}}
$$

where: $d_{b i}$ is the bubble diameter and $n_{i}$ is the number of bubbles.

A schematic representation of the experimental setup is shown in Fig. 2.

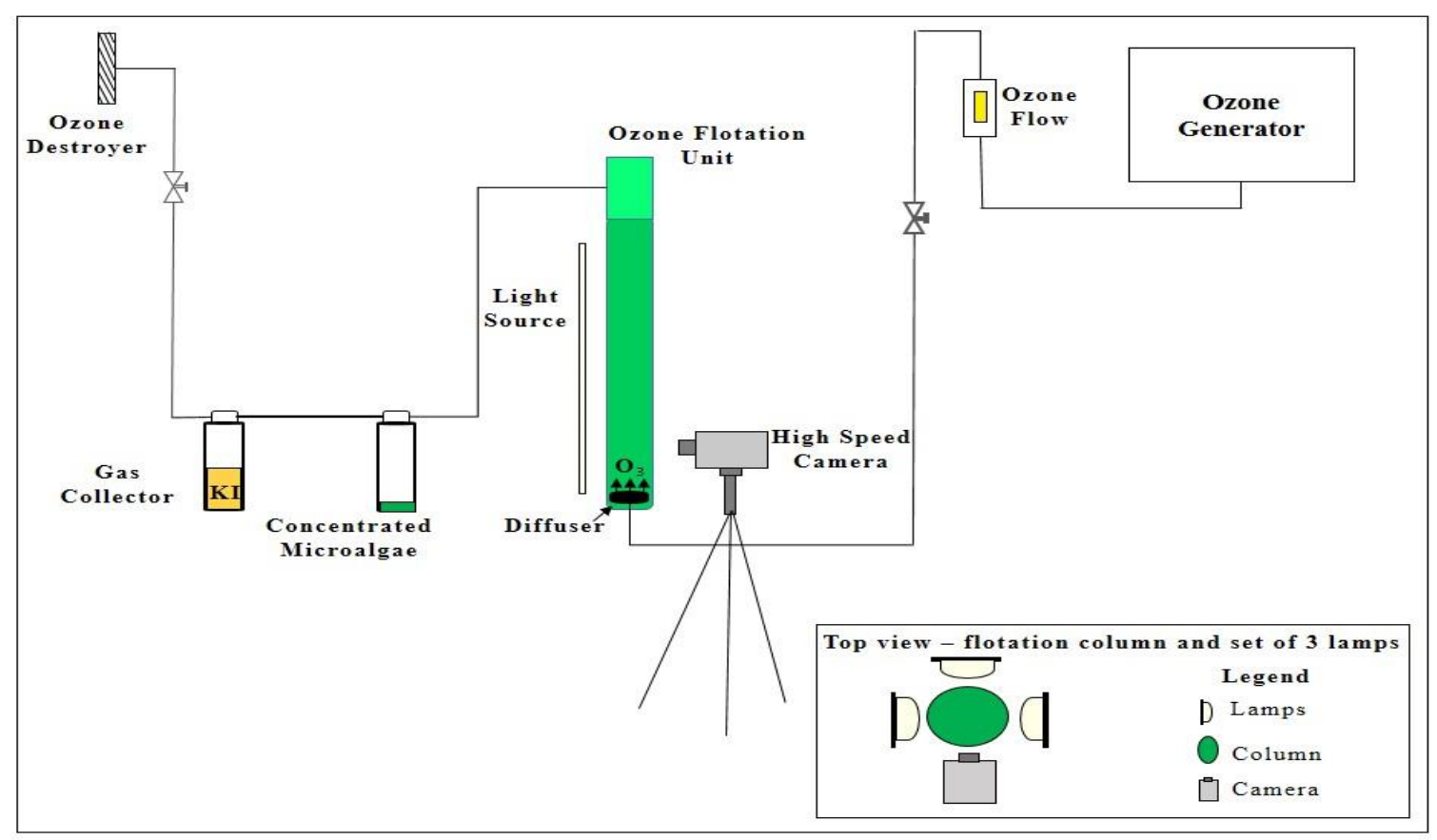

Fig. 2 Experimental setup for testing ozone-flotation to determine bubble size distribution. 


\section{Zeta potential}

Stabilization of the microalgae was determined by the zeta potential. The zeta potential of the microalgae culture (initial sample) was taken as a reference point to evaluate the effect of ozone on the cells after harvesting by ozone-flotation. After completion of the microalgae harvest by ozone-flotation (ozonation time for all tests was 20 minutes) the water remaining in the flotation column was then blended to obtain only one final sample for determination of the zeta potential. The zeta potential was measured with a particle sizing systems ZLS zeta module that fits into the Dynamic Light Scattering (DLS) technique, using Particle Sizing Systems equipment, NICOMP (model NICOMP 380 ZLS). This technique actually measures the electrophoretic mobility of the particles and converts this measurement to zeta potential based on Smoluchowski equation with sample temperature $25^{\circ} \mathrm{C}$. The determination was made in triplicate.

\section{Protein in the flotation column and in the harvested biomass}

The total protein content was determined by the Biuret colorimetric method as described by Gornall et al. [34]. From the harvested biomass, a $0.125 \mathrm{~g}$ portion was taken and $17 \mathrm{~mL}$ of water at $\mathrm{pH} 12$ was added and maintained for 1 hour at $40{ }^{\circ} \mathrm{C}$ under stirring. Afterwards, it was centrifuged to separate the supernatant from the proteins. Then $500 \mu \mathrm{L}$ of that supernatant was measured and $500 \mu \mathrm{L}$ of Milli Q water was added for analysis of the proteins in the harvested biomass. For the proteins in the flotation column, $1 \mathrm{~mL}$ of column water was filtered after ozonation. After measuring $1 \mathrm{~mL}$ from both forms, $4 \mathrm{~mL}$ of biuret reactive was added and stirred, then held for $30 \mathrm{~min}$ and read on a $\mathrm{HACH}$ spectrophotometer at $540 \mathrm{~nm}$.

\section{Experimental design}

For ozone-flotation, a design with two factors was proposed, with variables coded to represent the ozone flow rates $(0.2,0.6$ and $1 \mathrm{~L} / \mathrm{min})$ and column height at the bottom, middle and top $(3,25$ and $55 \mathrm{~cm}$, respectively). The design involved carrying out 27 experiments, each with three replicates. The influences of these operational variables were determined for the following responses: bubble size, particle size, mass transfer of ozone, protein in column flotation and biomass harvested, biomass recovery, oxidized biomass and zeta potential.

\section{Statistical analysis}

Statistical analyses were performed using statistical software MINITAB version 16. Data were tested for normality using an Anderson-Darling Normality Test. Normally distributed data were compared using an 
analysis of variance (ANOVA) at the 5\% significance level, to analyze and compare the experimental data the Tukey test was used. For data not normally distributed, a non-parametric analysis of variance (nonparametric ANOVA) was applied using the Mood's Median Test.

\section{Results}

\section{Ozone bubble size distribution and protein release in ozone-flotation}

The bubble size distribution from three heights in the flotation column and protein release within the different ozone flow conditions is shown in Fig. 3.

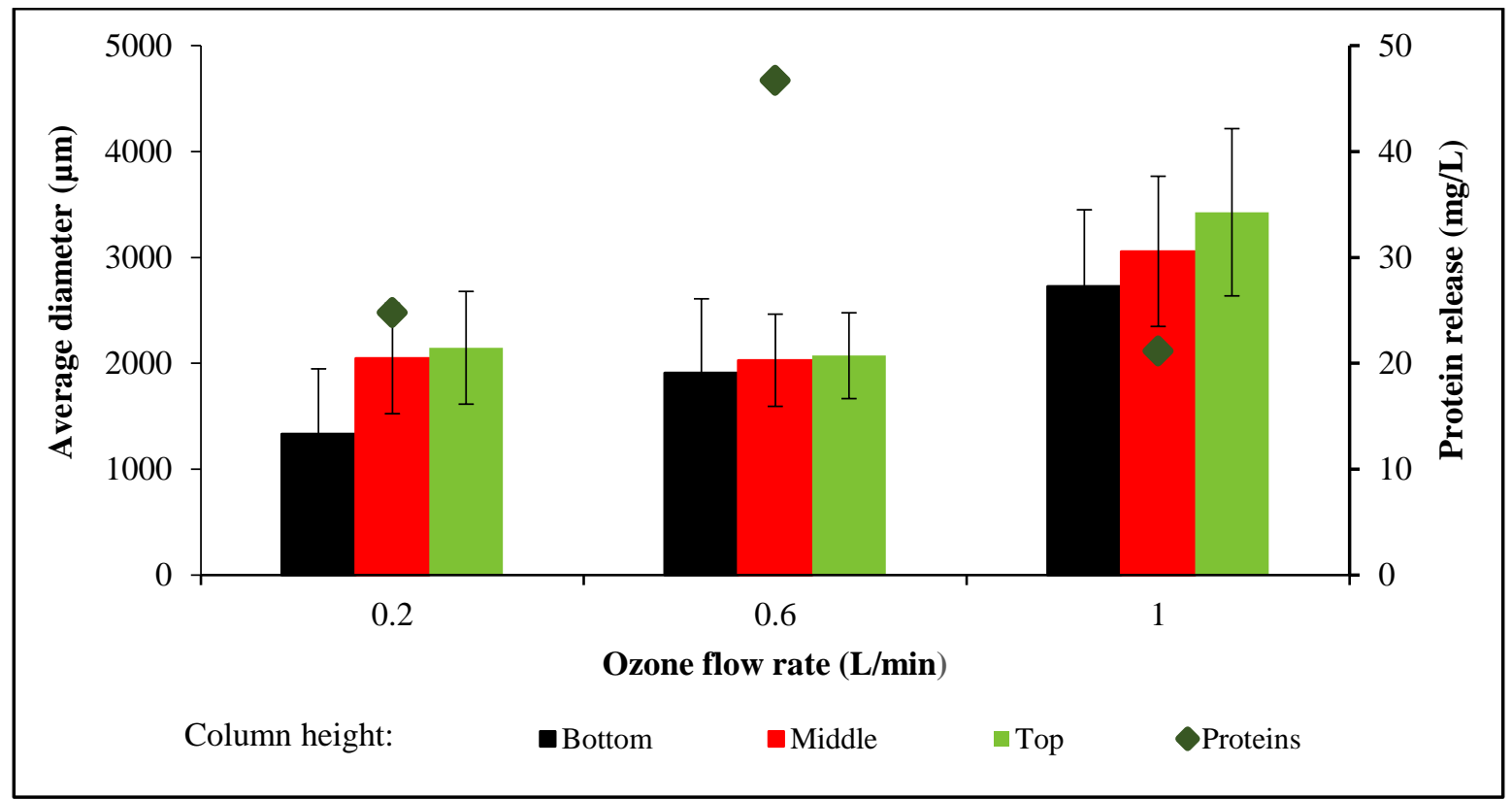

Fig 3. Average diameter of ozone bubble size at three heights (bottom, middle and top) in triplicate measured 900 bubbles the column and protein release with three ozone flow rates in ozone flotation.

Ozone bubble size is directly influenced by the ozone flow rate (p-value 0.000) (Table 1); the greater the $\mathrm{O}_{3}$ flow the larger the bubble size. The size varied from $1334 \pm 613.21 \mu \mathrm{m}$ (flow $0.2 \mathrm{~L} / \mathrm{min}$, bottom) to 3426 $\pm 699.35 \mu \mathrm{m}$ (flow $1 \mathrm{~L} / \mathrm{min}$, top). For flow rates of 0.2 or $1 \mathrm{~L} / \mathrm{min}$, a greater variation in bubble size was observed at different column heights, when compared to the flow rate of $0.6 \mathrm{~L} / \mathrm{min}$, produced a lower variation in ozone bubble size, and a higher protein release $(46.7 \pm 18.8 \mathrm{mg} / \mathrm{L})$ was found, already for the fluxes 0.2 and $1 \mathrm{~L} / \mathrm{min}$. the values of released proteins were low $(24.8 \pm 11.9$ and $21.2 \pm 14 \mathrm{mg} / \mathrm{L}$, respectively).

For a flow rate of $0.2 \mathrm{~L} / \mathrm{min}$, there was a statistical difference between the bottom and middle height bubbles, bottom and top bubbles (p-value 0.000), but not between middle and top bubbles (p-value 0.203). And 
for the $\mathrm{O}_{3}$ flow of $1 \mathrm{~L} / \mathrm{min}$, bubbles were different at all heights (p-value 0.000). At a flow rate of $0.6 \mathrm{~L} / \mathrm{min}$, there was no statistical difference between the bottom and middle (p-value 0.073) nor between the middle and top bubbles (p-value 0.479) (Table 1).

Table 1. Statistical results for ozone fluxes and column heights analyzed.

\begin{tabular}{cll|cll}
\hline O3 flow (L/min) & Column height & P-value & O3 flow (L/min) & Column height & P-value \\
\hline \multirow{2}{*}{0.2} & bottom/middle & 0.000 & & bottom/middle & 0.000 \\
& bottom/top & 0.000 & 1 & bottom/top & 0.000 \\
& middle/top & 0.203 & & middle/top & 0.000 \\
\hline \multirow{2}{*}{0.6} & bottom/middle & 0.073 & & bottom & 0.000 \\
& bottom/top & 0.055 & $0.2 / 0.6 / 1$ & middle & 0.000 \\
& middle/top & 0.479 & & top & 0.000 \\
\hline
\end{tabular}

The bubble size distribution differed according to flows used (Fig. 4a, b and c). A flow of $0.2 \mathrm{~L} / \mathrm{min}$ produced small bubbles at the bottom, and had a peak of 32\% of the bubbles between 500 and $1000 \mu \mathrm{m}$. The size of the bubbles increased in the middle and top, where there was the same frequency and size distribution of bubbles (Fig 3a), with a peak between 1500 and $2000 \mu \mathrm{m}$ with $34 \%$ of the bubbles in the mean and $33 \%$ of the bubbles in the top of that range with greater bubble concentrations found from 1000 to $3500 \mu \mathrm{m}$ with a Sauter diameter of $1834 \mu \mathrm{m}$ at the bottom, $2302 \mu \mathrm{m}$ in the middle and $2415 \mu \mathrm{m}$ at the top (Fig. d).
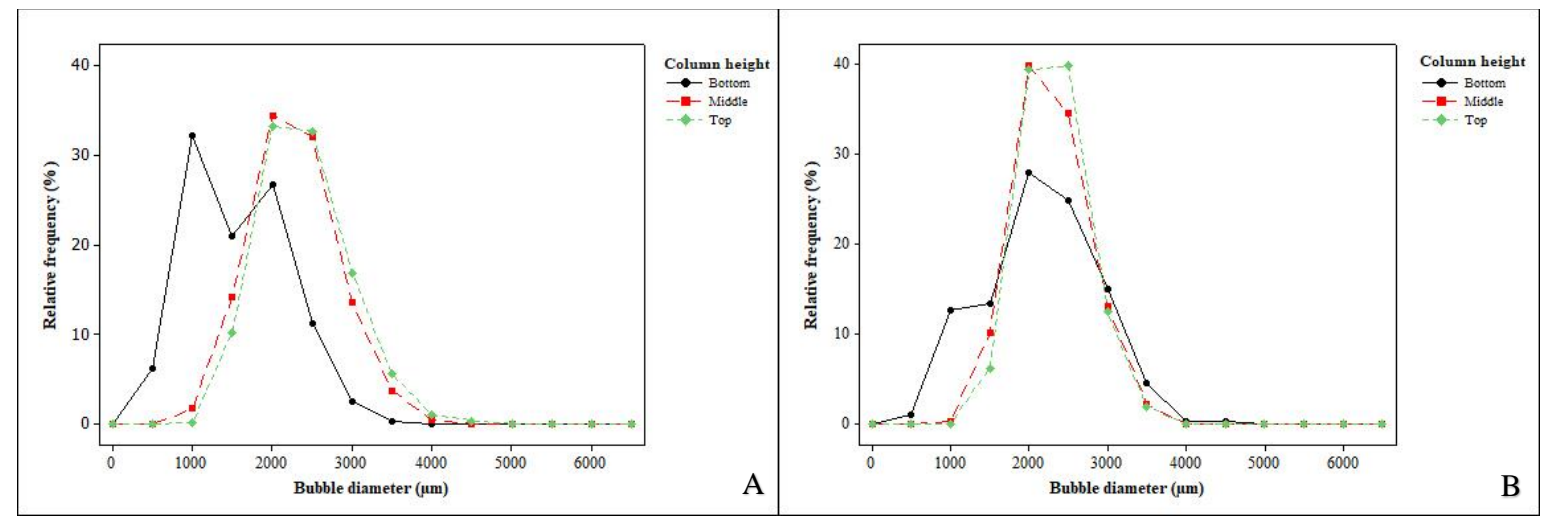


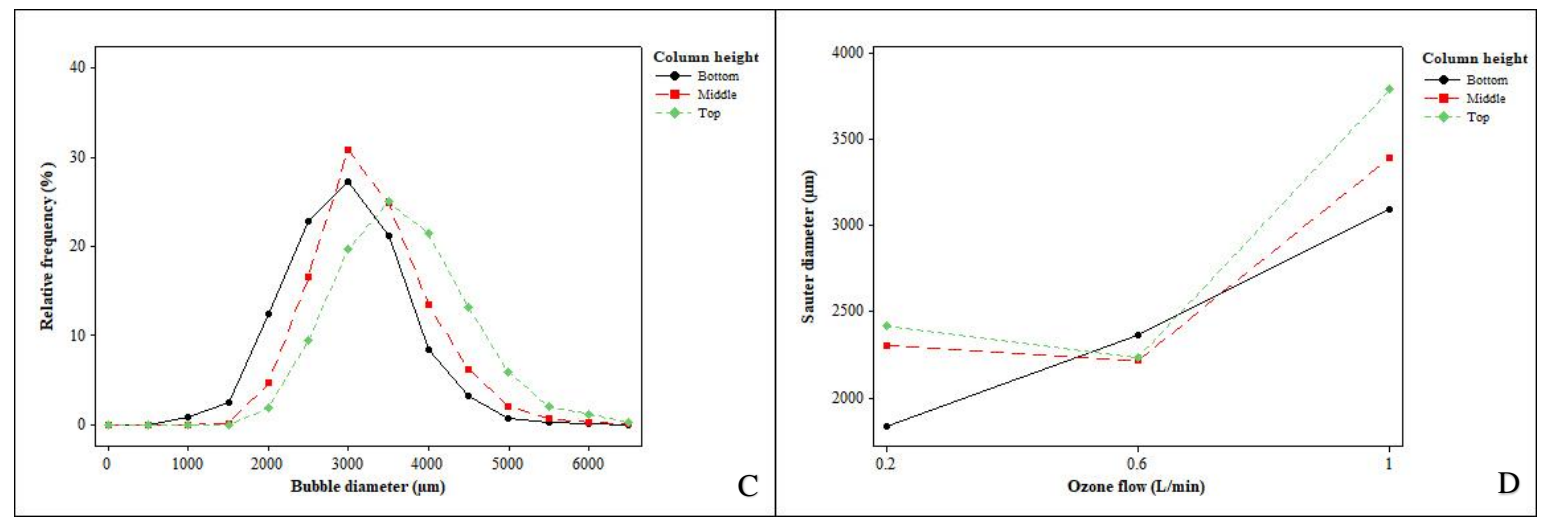

Fig 4. The relative frequency of bubble size distribution and Sauter mean diameter (D) in three heights in the column (bottom, middle and top) with ozone flows of $0.2(\mathrm{~A}), 0.6$ (B) and $1 \mathrm{~L} / \mathrm{min}$ (C) in triplicate measured 900 bubbles.

With a flow of $0.6 \mathrm{~L} / \mathrm{min}$ the distribution was more homogeneous. The majority of the bubbles were concentrated between 1500 and $3000 \mu \mathrm{m}$ (representing 81, 97.6 and $98 \%$ of the distribution, respectively). The distribution was maintained in the middle through the top of the column with a flow of $0.2 \mathrm{~L} / \mathrm{min}$ with a Sauter diameter of $2045 \mu \mathrm{m}$ for the bottom, $2028 \mu \mathrm{m}$ at the middle and $3057 \mu \mathrm{m}$ at the top (Fig. 4d).

For the flow rate of $1 \mathrm{~L} / \mathrm{min}$ the minimum diameter of the bubbles was not between 500 and $1000 \mu \mathrm{m}$ as it was for the other flow rates, and in fact bubbles with a diameter less than $1500 \mu \mathrm{m}$ were only in the lower part of the column. A significant size increase was found and the distribution is wider for the curves (Fig. 4c) for bubbles from 1500 to $5000 \mu \mathrm{m}$. The highest frequency of bubbles (Fig. 4c) was between 3000 and $4000 \mu \mathrm{m}$ ( $56.9 \%$ bottom, $69 \%$ middle and $66 \%$ top). In contrast to other flows $(0.2$ and $0.6 \mathrm{~L} / \mathrm{min})$ the bubbles reach a diameter up to $6500 \mu \mathrm{m}$ with Sauter diameters 2146, 2071 and $3426 \mu \mathrm{m}$ for the bottom, middle and top, respectively.

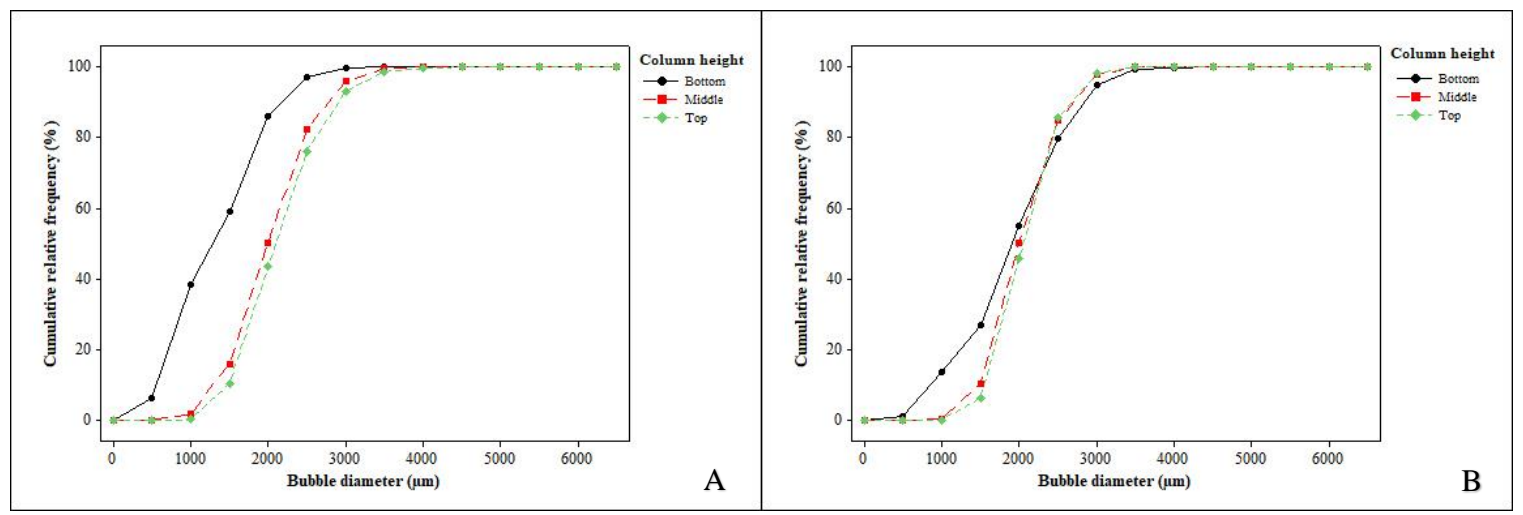




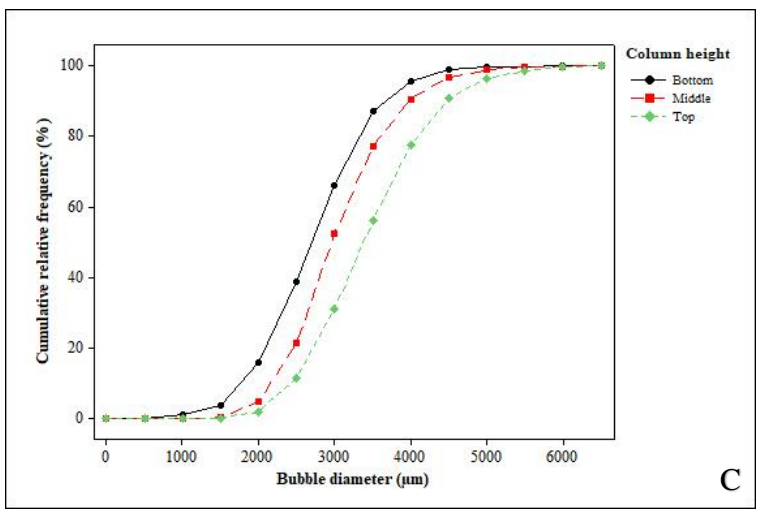

Fig 5. The cumulative relative frequency of bubble size distribution in three heights in the column with ozone flows $0.2(\mathrm{~A}), 0.6(\mathrm{~B})$ and $1 \mathrm{~L} / \mathrm{min}(\mathrm{C})$ in triplicate measured 900 bubbles.

In figure $5 \mathrm{a}$, the ozone flow of $0.2 \mathrm{~L} / \mathrm{min}$ shows the smallest bubble sizes and the largest difference between the heights (bottom, middle and top) in the column with a maximum diameter of $3500 \mu \mathrm{m}$, compared to the highest evaluated flows $(0.6$ and $1 \mathrm{~L} / \mathrm{min})$. For the flow of $0.2 \mathrm{~L} / \mathrm{min}$ in the lower part of the column, $59 \%$ of the bubbles are below $1500 \mu \mathrm{m}$, with $50 \%$ of the bubbles in the middle and $43.5 \%$ in the top at 2000 $\mu \mathrm{m}$. Already for the flow of $0.6 \mathrm{~L} / \mathrm{min}$ (Fig. $4 \mathrm{~b}$ ) the relative cumulative frequency did not show much difference between heights; $55 \%$ of the bubbles range in the size up to $2000 \mu \mathrm{m}$ and for the mean, $50.2 \%$ and $45.7 \%$ for the middle and top, respectively, however the cumulative relative frequency that was more concentrated up to $1500 \mu \mathrm{m}$ for the flow of $0.2 \mathrm{~L} / \mathrm{min}$ passed at $2000 \mu \mathrm{m}$. For the flow of $1 \mathrm{~L} / \mathrm{min}$ (Fig. $5 \mathrm{c}$ ) the cumulative relative frequency increases, most are concentrated between 2500 and $4500 \mu \mathrm{m}$, being $87 \%$ bottom, $77 \%$ middle and $56 \%$ top of the concentrated bubbles up to $3500 \mu \mathrm{m}$.

\section{Microalgae harvest}

Ozone flow rate had a great influence on harvested biomass and biomass oxidation during the ozoneflotation process. Figure 6 shows that the $\mathrm{O}_{3}$ flow rate of $0.6 \mathrm{~L} / \mathrm{min}$ was the most favorable and obtained the greatest harvest and oxidation of biomass. 


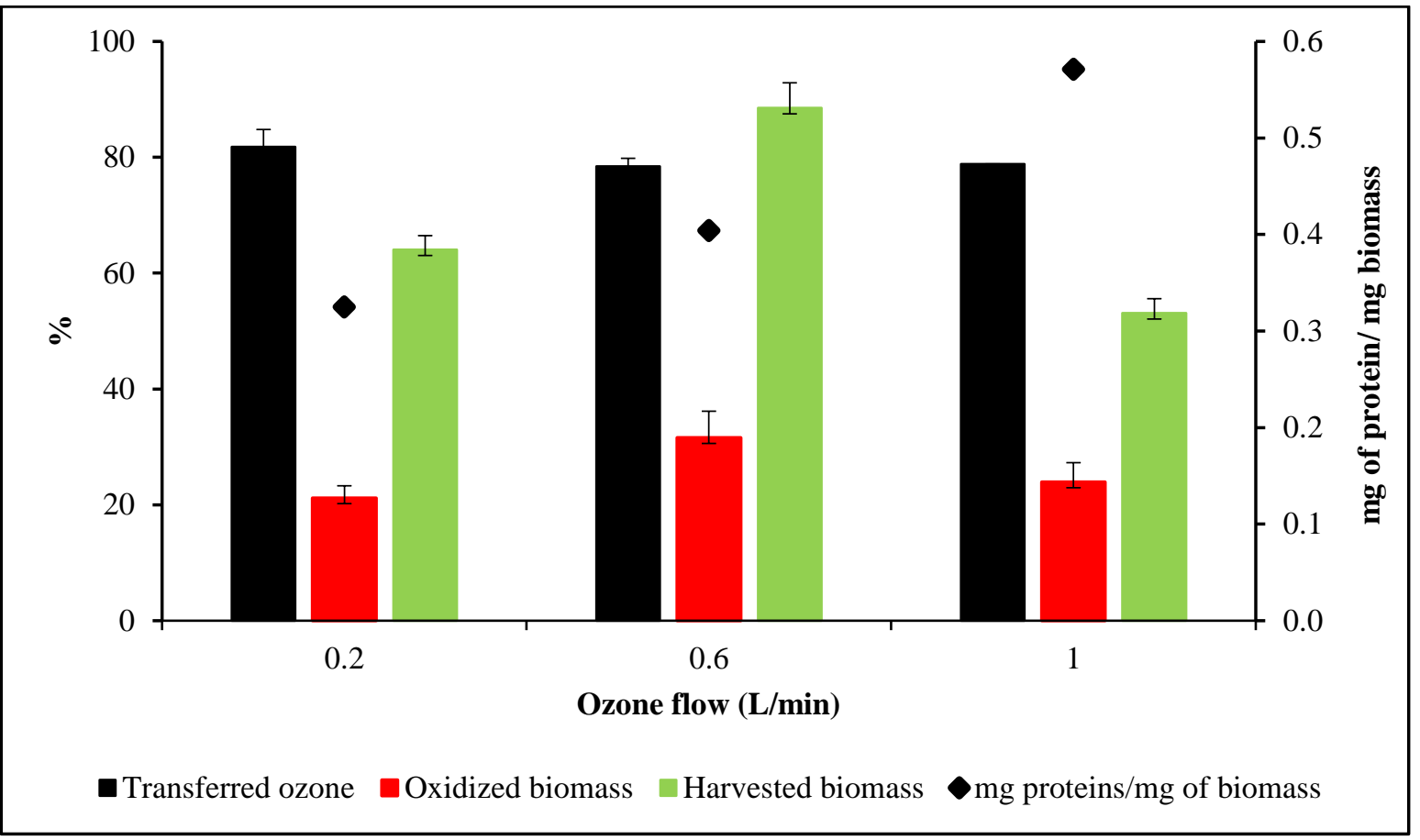

Fig 6. Percentage of transferred $\mathrm{O}_{3}$, oxidized biomass and biomass harvested in relation to ozone flow, and determination of proteins in biomass ( $\mathrm{SD}<0.08)$.

The transferred $\mathrm{O}_{3}$ had no significant difference for ozone flow (p-value 0.146), as opposed to oxidized biomass (p-value 0.006), harvested biomass (p-value 0.000) and proteins in harvested biomass (p-value 0.000 ). The effect of $\mathrm{O}_{3}$ flow on biomass produced the best results for the flow of $0.6 \mathrm{~L} / \mathrm{min}$ with $88.5 \%$ efficiency of ozone transfer and $31.6 \%$ of the initial biomass was oxidized by ozone; the oxidation variation in relation to the flow was $21.2 \%$ and $31.6 \%$ for the flow of 0.2 and $0.6 \mathrm{~L} / \mathrm{min}$, respectively. The oxidation of biomass by ozone was demonstrated from the visualization of Scenedesmus sp. by microscope after ozonation (Fig. 7), which produced sizes smaller than $1 \mu \mathrm{m}$, with an average of $0.93 \pm 0.19 \mu \mathrm{m}$ and was compared to the size of the initials cells that had a $\mathrm{D}_{90}$ of $3.57 \pm 0.008 \mu \mathrm{m}$ and an average diameter of $2.2 \pm 0.03 \mu \mathrm{m}$. Scenedesmus sp. have an approximated size of 6 to $20 \times 3$ to $10 \mu \mathrm{m}$, its morphology is unicellular as well as coenobia of 2, 4 and 8 cells $[35,36]$.

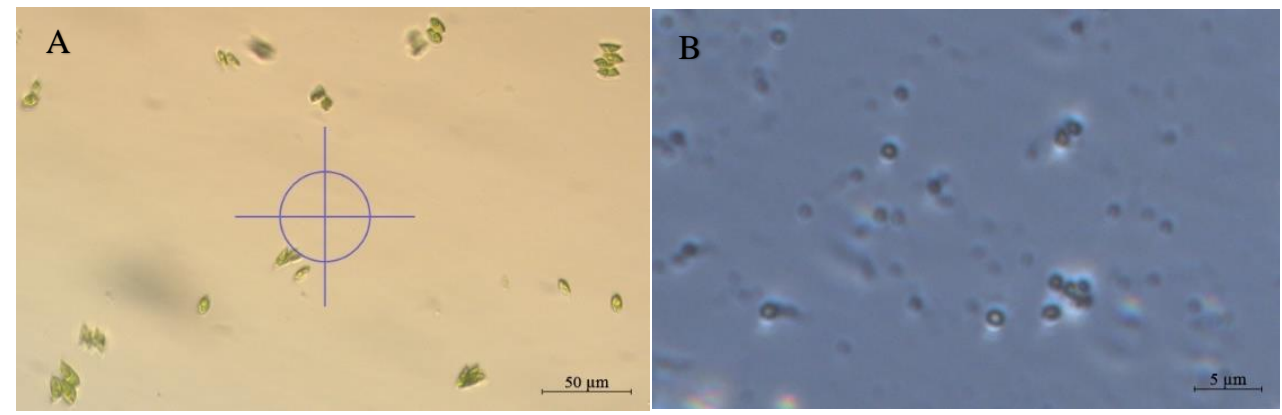


Fig 7. Cells of Scenedesmus sp. before the application of ozone flotation with 40x magnification (A) and after application with a flow of $0.6 \mathrm{~L} / \mathrm{min} 100 \mathrm{x}$ magnification (B).

The lowest efficiency was found when the $\mathrm{O}_{3}$ flow was applied at $1 \mathrm{~L} / \mathrm{min}$, with an efficiency of 53\%, $35.5 \%$ lower than the higher efficiency $(88.5 \%)$. However for the proteins in the biomass harvested, the flow of $1 \mathrm{~L} / \mathrm{min}$ was more efficient with $0.57 \pm 0.03 \mathrm{mg}$ of proteins/mg of biomass, approximately $30 \%$ higher than when using a flow of $0.6 \mathrm{~L} / \mathrm{min}$.

The initial zeta potential of the microalgae was $-15 \pm 1.4 \mathrm{mV}$ and a $\mathrm{pH}$ of about 8 . After the ozoneflotation process, the zeta potential was different for each $\mathrm{O}_{3}$ flow evaluated (Fig. 8).

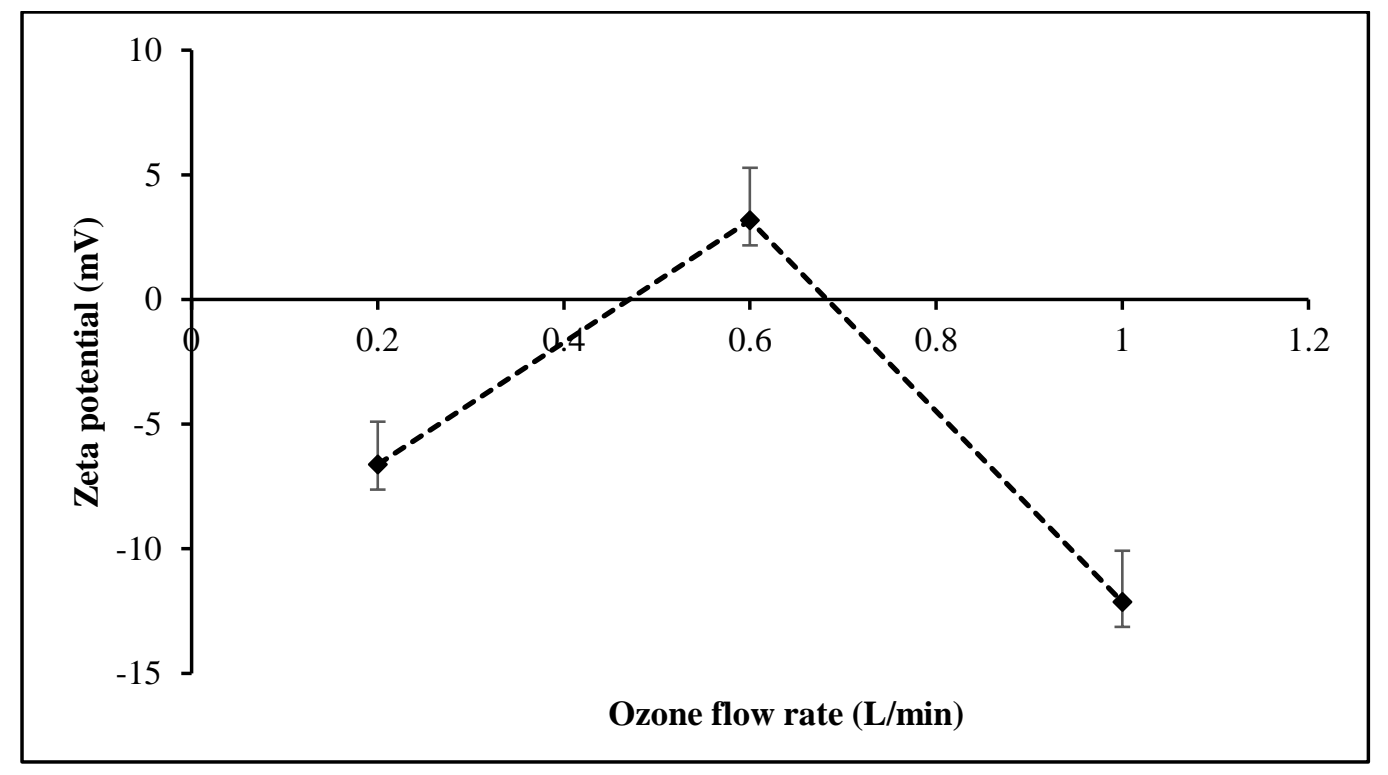

Fig 8. Zeta potential after ozone-flotation.

For ozone flows of 0.2 and $1 \mathrm{~L} / \mathrm{min}$ the microalgal loads after ozonation remained negative, but less negative than initially $(-6.6$ and $-12.1 \mathrm{mV}$, respectively). For the flow of $0.6 \mathrm{~L} / \mathrm{min}$ the charge of the microalgae was positive $(3.17 \mathrm{mV})$.

\section{Discussion}

\section{Ozone bubble size distribution and protein release in ozone-flotation}

The photographic methods in combination with digital imaging is apparently a promising solution to obtain reliable measurements of bubble size in three-phase systems [37]. The fragile structure of the ozone bubbles present in flotation columns and the possibility of agglutination and dissolution are the main causes of 
deformation of the results when intrusive or offline (extraction of samples) methods are applied. In this study, the direct image capture method (online) was used in the real time flotation column, without the extraction of bubbles. However in the work of Reis and Barrozo [24] the same trends were obtained for the results using the offline and online method.

The size of the bubble increases with increasing ozone flow due to the larger volume of gas entering the system, this increase was also observed by Reis and Barrozo [24]. ]." Increased superficial gas velocity increases the bubble collision frequency leading to a higher coalescence rate and an increased stable bubble diameter [38]. For the ozone flow of $0.6 \mathrm{~L} / \mathrm{min}$, there was no significant difference in bubble size at the 3 heights of the column evaluated, probably due to higher protein extraction, which, unlike the other flows $(0.2$ and 1 $\mathrm{L} / \mathrm{min}$ ), showed an increase $\left(54.7 \%\right.$ for the $\mathrm{O}_{3}$ flow of $0.2 \mathrm{~L} / \mathrm{min}$ and $46.8 \%$ for $1 \mathrm{~L} / \mathrm{min}$ ). The proteins released by the microalgae exhibit surfactant activity, thus reducing the surface tension of bubbles and avoiding coalescence [39].

Each ozone flow and each column height produced significantly different Sauter mean diameters, with smaller diameters at the bottom that increased to the top. Bubbles carrying particles can be brought together in a turbulent vortex resulting in bubble coalescence and consequent detachment of particles. Inertial detachments have also been found, due to rapid changes in the trajectory of the bubble, or because of oscillations of the bubble's surface [12].

Through visual observations, it was observed that at the beginning of the ozone flotation process, the bubbles were less uniform and greater coalescence could be observed. With the passage of time and greater reaction of the ozone with the microalgae cells, the bubbles became uniform with less coalescence. However, at the end of the process the bubbles return to as they were in the beginning of the process due to the low concentration of microalgae and a consequent a reduction in proteins. In this case the application of ozone oxidizes the cells, releasing proteins that act as biosurfactants, reducing the superficial charge of the cells and avoiding the coalescence of bubbles, in addition to increasing the extraction of biomolecules due to their oxidizing action.

\section{Microalgal harvesting}

In microalgae harvesting two processes predominate, the chemical reaction of ozone with microalgae and a physical process that favor the flotation of microalgae. Small bubbles increase the chance of bubbleparticle contact, but very small bubbles have a low rate of ascent. Very large bubbles are also not favorable because they decrease bubble-particle interaction. Coward et al. [14] described the mechanism of bubble formation as a function of bubble size and elevation velocity as a key feature that significantly affects the efficiency of harvesting microalgae.

In this process, a biomass harvesting efficiency of up to $88.5 \%$ and $0.404 \pm 0.08 \mathrm{mg}$ of proteins $/ \mathrm{mg}$ of biomass was obtained for an ozone flow of $0.6 \mathrm{~L} / \mathrm{min}$ and doses of ozone applied at $0.16 \mathrm{mg} \mathrm{O}_{3} / \mathrm{mg}$ of biomass. Valeriano-González et al. [39] with $0.14 \mathrm{mg} \mathrm{O} / \mathrm{mg}$ of biomass and ozone flow $0.2 \mathrm{~L} / \mathrm{min}$ obtained a lower 
efficiency (75\%), for a lower concentration of microalgae (400 mg/L) and Oliveira et al. [40] obtained a biomass recovery of $62 \%$ and $0.58 \mathrm{mg}$ of proteins $/ \mathrm{mg}$ of biomass. The highest release of proteins obtained by the authors was due to the higher concentration of initial biomass $(800 \mathrm{mg} / \mathrm{L}$ and $1200 \mathrm{mg} / \mathrm{L})$, using the same species of microalgae (Scenedesmus sp.) and $0.14 \mathrm{mg} \mathrm{O} / \mathrm{mg}$ of biomass. Velasquez-Orta et al. [41] obtained a biomass recovery of $79 \%$, using higher doses of ozone $\left(0.23 \mathrm{mg} \mathrm{O}_{3} / \mathrm{mg}\right.$ of biomass $)$ and lower microalgal concentration (420 mg SST/L) than in this study $\left(0.16 \mathrm{mg} \mathrm{O}_{3} / \mathrm{mg}\right.$ of dry biomass and a $500 \mathrm{mg} \mathrm{SST} / \mathrm{L}$ biomass concentration).

It was observed that efficiency is dependent on the flow of ozone applied. For the flow of $1 \mathrm{~L} / \mathrm{min}$ it was not possible to obtain high efficiency due to shorter contact time and larger size of bubbles. For the flow of $0.2 \mathrm{~L} / \mathrm{min}$, the low efficiency was previously explained by low bubble flotation velocity and thus particle detachment, which may also be related to the negative zeta potential of the microalgae. However, for the flow of $0.6 \mathrm{~L} / \mathrm{min}$, there was a low stability of colloids with positive zeta potential $(+3.2)$, which favored the high efficiency of microalgae harvest $(88.5 \%)$ and oxidation of cells $(31.6 \%)$ reducing its size to less than $1 \mu \mathrm{m}$. The increase in zeta potential at $0.6 \mathrm{~L} / \mathrm{min}$ flow rate, It occurred because there is more efficient contact between the bubbles and the particles, when there is a more homogeneous bubble size in the column and so highest microalgae harvesting (shown in Fig. 6), where the proteins may change the microalgae surface charge into slightly positive. Proteins are amphiphilic molecules that reduce surface tension and promote foaming [42], allowing microalgae harvesting and change in zeta potential. The decrease in algal size could be a result of disintegration of EOM from algal surface [43] or generation of algal debris due to cell lysis [44]. According to Tsang et al. [45] the contact time between the bubble and the particle depends on the flow rate of the gas, the higher the flow the shorter the contact time, and they demonstrated that coalescence behavior is independent of time of contact. Besides observing that for the flows of 0.2 and $1 \mathrm{~L} / \mathrm{min}$ there was lower efficiency and greater coalescence of ozone bubbles, according to Ata [46], the particles detached from the bubble surfaces as a result of the oscillations caused by coalescence.

\section{Conclusions}

Ozone-flotation bubble size distribution is one of the main characteristics that influences harvesting efficiency. For the flow of $0.2 \mathrm{~L} / \mathrm{min}$ in the lower part of the column, $59 \%$ of the bubbles are below $1500 \mu \mathrm{m}$, with $50 \%$ of the bubbles in the middle and $43.5 \%$ in the top at $2000 \mu \mathrm{m}$. For the flow of $0.6 \mathrm{~L} / \mathrm{min}$ the relative cumulative frequency did not show much difference between heights, $55 \%$ of the bubbles are below $2000 \mu \mathrm{m}$ (bottom), $50.2 \%$ (middle) $45.7 \%$ (top). And for the flow of $1 \mathrm{~L} / \mathrm{min}$ the size of the bubbles increases, being that the most are concentrated between 2500 and $4500 \mu \mathrm{m}$ for the 3 columns height. The ozone flow of $0.6 \mathrm{~L} / \mathrm{min}$ produced the most effective algal harvesting, liberation of proteins in the flotation column, biomass oxidation, greater destabilization of particles, and especially greater action of proteins a as biosurfactant that reduce the coalescence of ozone bubbles for a biomass concentration of $500 \mathrm{mg} / \mathrm{L}$ of microalgae grown in wastewater.

\section{Acknowledgements}


The authors acknowledge MSc. Isaura Yáñez-Noguez for her laboratory support and thanks to MEng. Calina Grazielli for her support with the figure of the experimental structure. This research project was supported by the Fondo Sectorial de Sustentabilidad Energética CONACYT-SENER, project 220704.

\section{References}

[1] C. Xin, M.M. Addy, J. Zhao, Y. Cheng, S. Cheng, D. Mu, Y. Liu, R. Ding, P. Chen, R. Ruan, Comprehensive techno-economic analysis of wastewater-based algal biofuel production: A case study, Bioresour. Technol. 211 (2016) 584-593. doi:10.1016/j.biortech.2016.03.102.

[2] V.G. Gude, Wastewater treatment in microbial fuel cells - An overview, J. Clean. Prod. 122 (2016) 287-307. doi:10.1016/j.jclepro.2016.02.022.

[3] J.I. Labbé, J.L. Ramos-Suárez, A. Hernández-Pérez, A. Baeza, F. Hansen, Microalgae growth in polluted effluents from the dairy industry for biomass production and phytoremediation, J. Environ. Chem. Eng. 5 (2017) 635-643. doi:10.1016/j.jece.2016.12.040.

[4] H. Qari, M. Rehan, A.S. Nizami, Key Issues in Microalgae Biofuels: A Short Review, Energy Procedia. 142 (2017) 898-903. doi:10.1016/j.egypro.2017.12.144.

[5] M.L. Gerardo, S. Van Den Hende, H. Vervaeren, T. Coward, S.C. Skill, Harvesting of microalgae within a biorefinery approach: A review of the developments and case studies from pilot-plants, Algal Res. 11 (2015) 248-262. doi:10.1016/j.algal.2015.06.019.

[6] Y.S. Cho, J.S. Laskowski, Effect of flotation frothers on bubble size and foam stability, Int. J. Miner. Process. 64 (2002) 69-80. doi:10.1016/S0301-7516(01)00064-3.

[7] N. Uduman, Y. Qi, M.K. Danquah, G.M. Forde, A. Hoadley, Dewatering of microalgal cultures: A major bottleneck to algae-based fuels, J. Renew. Sustain. Energy. 2 (2010). doi:10.1063/1.3294480.

[8] D. Vandamme, I. Foubert, K. Muylaert, Flocculation as a low-cost method for harvesting microalgae for bulk biomass production, Trends Biotechnol. 31 (2013) 233-239. doi:10.1016/j.tibtech.2012.12.005.

[9] S.B. Ummalyma, A.K. Mathew, A. Pandey, R.K. Sukumaran, Harvesting of microalgal biomass: Efficient method for flocculation through pH modulation, Bioresour. Technol. 213 (2016) 216-221. doi:10.1016/j.biortech.2016.03.114.

[10] N. Betzer, Y. Argaman, Y. Kott, Effluent treatment and algae recovery by ozone-induced flotation, Water Res. 14 (1980) 1003-1009. doi:10.1016/0043-1354(80)90144-X.

[11] A. Hassanzadeh, B.V. Hassas, S. Kouachi, Z. Brabcova, M.S. Çelik, Effect of bubble size and velocity on collision efficiency in chalcopyrite flotation, Colloids Surfaces A Physicochem. Eng. Asp. 498 (2016) 258-267. doi:10.1016/j.colsurfa.2016.03.035.

[12] G. Wang, G.M. Evans, G.J. Jameson, Bubble movement in a rotating eddy : The implications for particle-bubble detachment, Chem. Eng. Sci. 161 (2017) 329-340. doi:10.1016/j.ces.2016.12.034.

[13] C.H. Wong, M.M. Hossain, C.E. Davies, Performance of a continuous foam separation column as a 
function of process variables, Bioprocess Biosyst. Eng. 24 (2001) 73-81. doi:10.1007/s004490100225.

[14] T. Coward, J.G.M. Lee, G.S. Caldwell, The effect of bubble size on the efficiency and economics of harvesting microalgae by foam flotation, J. Appl. Phycol. 27 (2015) 733-742. doi:10.1007/s10811014-0384-5.

[15] Z. Brabcová, T. Karapantsios, M. Kostoglou, P. Basařová, K. Matis, Bubble-particle collision interaction in flotation systems, Colloids Surfaces A Physicochem. Eng. Asp. 473 (2014) 95-103. doi:10.1016/j.colsurfa.2014.11.040.

[16] J. Ralston, D. Fornasiero, R. Hayes, Bubble - particle attachment and detachment in flotation, (1999) $133-164$.

[17] R. Maxwell, S. Ata, E.J. Wanless, R. Moreno-Atanasio, Computer simulations of particle-bubble interactions and particle sliding using Discrete Element Method, J. Colloid Interface Sci. 381 (2012) 1-10. doi:10.1016/j.jcis.2012.05.021.

[18] Y. Xing, X. Gui, Y. Cao, Effect of bubble size on bubble-particle attachment and fi lm drainage kinetics - A theoretical study, Powder Technol. 322 (2017) 140-146. doi:10.1016/j.powtec.2017.09.007.

[19] V. Sarrot, P. Guiraud, D. Legendre, Determination of the collision frequency between bubbles and particles in flotation, Chem. Eng. Sci. 60 (2005) 6107-6117. doi:10.1016/j.ces.2005.02.018.

[20] A.V. Nguyen, H.J. Schulze, J. Ralston, Elementary steps in particle—bubble attachment, Int. J. Miner. Process. 51 (1997) 183-195. doi:10.1016/S0301-7516(97)00030-6.

[21] C.M. Phan, A. V. Nguyen, J.D. Miller, G.M. Evans, G.J. Jameson, Investigations of bubble-particle interactions, Int. J. Miner. Process. 72 (2003) 239-254. doi:10.1016/S0301-7516(03)00102-9.

[22] R.T. Rodrigues, J. Rubio, New basis for measuring the size distribution of bubbles, Miner. Eng. 16 (2003) 757-765. doi:10.1016/S0892-6875(03)00181-X.

[23] J. Hanotu, H.C.H. Bandulasena, W.B. Zimmerman, Microflotation performance for algal separation, Biotechnol. Bioeng. 109 (2012) 1663-1673. doi:10.1002/bit.24449.

[24] A.S. Reis, M.A.S. Barrozo, A study on bubble formation and its relation with the performance of apatite flotation, Sep. Purif. Technol. 161 (2016) 112-120. doi:10.1016/j.seppur.2016.01.038.

[25] Y.L. Cheng, Y.C. Juang, G.Y. Liao, P.W. Tsai, S.H. Ho, K.L. Yeh, C.Y. Chen, J.S. Chang, J.C. Liu, W.M. Chen, D.J. Lee, Harvesting of Scenedesmus obliquus FSP-3 using dispersed ozone flotation, Bioresour. Technol. 102 (2011) 82-87. doi:10.1016/j.biortech.2010.04.083.

[26] R.A. Grau, K. Heiskanen, Bubble size distribution in laboratory scale flotation cells, Miner. Eng. 18 (2005) 1164-1172. doi:10.1016/j.mineng.2005.06.011.

[27] A. Vazirizadeh, J. Bouchard, Y. Chen, Effect of particles on bubble size distribution and gas hold-up in column flotation, Int. J. Miner. Process. 157 (2016) 163-173. doi:10.1016/j.minpro.2016.10.005.

[28] C. Wu, L. Wang, D. Harbottle, J. Masliyah, Z. Xu, Studying bubble-particle interactions by zeta potential distribution analysis, J. Colloid Interface Sci. 449 (2015) 399-408.

doi:10.1016/j.jcis.2015.01.040. 
[29] Z. Chen, S. Ata, G.J. Jameson, Behaviour of bubble clusters in a turbulent flotation cell, Powder Technol. 269 (2015) 337-344. doi:10.1016/j.powtec.2014.09.025.

[30] M.H. Chegeni, M. Abdollahy, M.R. Khalesi, Bubble loading measurement in a continuous flotation column, Miner. Eng. 85 (2016) 49-54. doi:10.1016/j.mineng.2015.08.010.

[31] C.E. Cilek, S. Karaca, Effect of nanoparticles on froth stability and bubble size distribution in $\mathrm{fl}$ otation, Int. J. Miner. Process. 138 (2015) 6-14. doi:10.1016/j.minpro.2015.03.004.

[32] D. Beneventi, F. Almeida, N. Marlin, D. Curtil, L. Salgueiro, M. Aurousseau, Hydrodynamics and recovered papers deinking in an ozone flotation column, Chem. Eng. Process. Process Intensif. 48 (2009) 1517-1526. doi:10.1016/j.cep.2009.10.007.

[33] C.. Birdsall, A.C. Jenkins, E. Spadinger, Iodometric Determination of Ozone, Anal. Chem. 24 (1952) 662-664. doi:10.1021/ac60064a013.

[34] A.G. Gornall, charles j. Bardawill, M.M. David, Determination of serum proteins by means of the biuret reaction, J. Biol. Chem. 177 (1948) 751-766.

[35] F.J. Tavera, R. Escudero, J.A. Finch, Gas holdup in flotation columns: Laboratory measurements, Int. J. Miner. Process. 61 (2001) 23-40. doi:10.1016/S0301-7516(00)00026-0.

[36] S.S. An, T. Friedl, E. Hegewald, Phylogenetic Relationships of Scenedesmus and Scenedesmus-like Coccoid Green Algae as Inferred from ITS-2 rDNA Sequence Comparisons, Plant Biol. 1 (1999) $418-428$.

[37] R.A. Grau, K. Heiskanen, Visual technique for measuring bubble size in flotation machines, Miner. Eng. 15 (2002) 507-513. doi:10.1016/S0892-6875(02)00074-2.

[38] R. Schäfer, C. Merten, G. Eigenberger, Bubble size distributions in a bubble column reactor under industrial conditions, Exp. Therm. Fluid Sci. 26 (2002) 595-604. doi:10.1016/S0894-1777(02)001899.

[39] M.T. Valeriano González, I. Monje-Ramírez, M.T. Orta Ledesma, J. Gracia Fadrique, S.B. Velásquez-Orta, Harvesting microalgae using ozoflotation releases surfactant proteins, facilitates biomass recovery and lipid extraction, Biomass and Bioenergy. 95 (2016) 109-115. doi:10.1016/j.biombioe.2016.09.020.

[40] G.A. Oliveira, E. Carissimi, I. Monje-ramírez, S.B. Velasquez-orta, R.T. Rodrigues, M.T. Orta Ledesma, Comparison between coagulation-flocculation and ozone-flotation for Scenedesmus microalgal biomolecule recovery and nutrient removal from wastewater in a high-rate algal pond, Bioresour. Technol. 259 (2018) 334-342. doi:10.1016/j.biortech.2018.03.072.

[41] S.B. Velasquez-Orta, R. Garcia-Estrada, I. Monje-Ramirez, A. Harvey, M.T. Orta Ledesma, Microalgae harvesting using ozoflotation: Effect on lipid and FAME recoveries, Biomass and Bioenergy. 70 (2014) 356-363. doi:10.1016/j.biombioe.2014.08.022.

[42] C.N. Mulligan, Environmental applications for biosurfactants, Environ. Pollut. 133 (2005) $183-198$. doi:10.1016/j.envpol.2004.06.009.

[43] S. Babel, S. Takizawa, Chemical pretreatment for reduction of membrane fouling caused by algae, DES. 274 (2011) 171-176. doi:10.1016/j.desal.2011.02.008. 
[44] M.T. Hung, J.C. Liu, Microfiltration for separation of green algae from water, 51 (2006) 157-164. doi:10.1016/j.colsurfb.2006.07.003.

[45] Y.H. Tsang, Y.H. Koh, D.L. Koch, Bubble-size dependence of the critical electrolyte concentration for inhibition of coalescence, J. Colloid Interface Sci. 275 (2004) 290-297. doi:10.1016/j.jcis.2004.01.026.

[46] S. Ata, Journal of Colloid and Interface Science, J. Colloid Interface Sci. 338 (2009) 558-565. doi:10.1016/j.jcis.2009.07.003. 